\title{
EVALUASI KINERJA KEPALA SEKOLAH MENENGAH KEJURUAN NEGERI DI KOTA BANDAR LAMPUNG
}

\author{
Yetri \\ Fakultas Tarbiyah dan Keguruan, IAIN Lampung \\ Jl. Endro Suratmin No. 23 Sukarame Bandar Lampung \\ uncuyetri@yahoo.co.id
}

\begin{abstract}
Abstrak:
Tujuan penelitian ini adalah untuk mengetahui kesesuaian antara prinsip-prinsip kinerja yang digunakan dalam menunaikan tugas managerial dengan standar kinerja yang telah ditetapkan, meliputi: (1) upaya memajukan sekolah dalam konteks pemanfaatan sumber-sumber sekolah secara optimal; (2) mengelola perubahan-perubahan dan pengembangan sekolah menuju organisasi belajar yang efektif; (3) menciptakan budaya dan suasana sekolah yang kondusif dan inovatif; (4) penggunaan ICT dalam pembelajaran dan manajemen sekolah. Penelitian menggunakan pendekatan evaluasi sebagai dengan model goal based yang secara umum dikembangkan sebagai model mengevaluasi lembagalembaga pemerintahan. Penelitian menggunakan metode kualitatif. Data dikumpulkan dengan menggunakan observasi, wawancara dan dokumentasi. Hasilnya menunjukkan: (1) kinerja kepemimpinan di sekolah sudah dalam kategori baik, (2) prinsip-prinsip kinerja dalam mengelola perubahan dan pengembangan sekolah dalam kategori baik, (3) prinsip-prinsip kinerja dalam menciptakan budaya dan suasana sekolah dalam kategori baik, (4) prinsipprinsip kinerja dalam menggunakan ICT pembelajaran serta pengelolaan sekolah dalam kategori baik. Kesimpulannya adalah, dari empat aspek prinsip kinerja yang dievaluasi, tiga diantaranya dalam kategori baik dan satu diantaranya kategori cukup.
\end{abstract}

\begin{abstract}
:
The objective of this research was to determine the suitability of the principals' performance in carrying out managerial tasks with the established standards, including performance in: (1) leading the school in the context of the utilization of school resources optimally, (2) managing changes and development of the school towards an effective learning organization, (3) creating a culture and school climate which are conducive and innovative, and (4) utilizing the advancement of ICT in learning and school management. The approach and evaluation model chosen in this study was a goal-based evaluation model which was combined with evaluation model that were generally developed in several government institutions. The research method was qualitative. The data were collected by using observation, interview, and documents. The results of the research showed that: (1) the performance of the principals in leading the school were in good category, (2) the performance of the principals in managing change and school development were in good category, (3) the performance of the principal in creating a culture and school climate were in good category, and (4) the performance of the principal in the use of ICT in teaching and school management were in enough category. The conclusion of the research was, of the four aspects of the performance of principals evaluated, three of them showed the achievement of performance was good category, and one aspect was in enough
\end{abstract}


category. However, in each aspect in the evaluation there were still some performance criteria that have not been achieved well, or there were still in the enough category.

Kata Kunci:

Kinerja, tugas-tugas manajerial, prinsip-prinsip, evaluasi

PERSAINGAN dan kerjasama global memunculkan tantangan baru yang harus dihadapi oleh setiap negara dewasa ini. Kemampuan untuk memenangkan persaingan tersebut tentu saja ditentukan oleh kualitas sumber daya manusia yang dimilikii. Jalur pendidikan kejuruan adalah merupakan salah satu upaya strategis untuk mempersiapkan sumber daya manusia berkualitas yang siap bertarung pada era ini.

Menurut Suyanto berbagai persoalan dalam pengembangan pendidikan SMK dewasa ini masih menjadi keprihatinan banyak pihak, terutama berkaitan dengan efektivitas dan efisiensi dalam proses pengelolaan dan pembelajaran. Hal ini ditandai oleh beberapa indikasi, diantaranya adalah masih tingginya angka pengangguran lulusan SMK di Indonesia. Fenomena di atas disinyalir sebagai akibat dari rendahnya kualitas lulusan, dan rendahnya kualitas lulusan (output) juga tidak terlepas dari rendahnya kinerja guru dan kepala sekolah sebagai tokoh kunci penentu keberhasilan sebuah sekolah. ${ }^{1}$

Kepala sekolah atau school principal menurut Karwati \& Priansa adalah pejabat profesional yang ada dalam organisasi sekolah yang bertugas untuk mengatur semua sumber daya sekolah mencapai tujuan pendidikan. Merupakan input terpenting sekolah yang memiliki tugas, fungsi dan tanggung jawab yang sangat besar dalam mencapai tujuan sekolah. ${ }^{2}$ Begitu strategisnya kedudukan kepala sekolah, maka sudah sepatutnya kepala sekolah memiliki berbagai kompetensi memadai yang relevan dengan tugasnya, salah satunya adalah kompetensi manajerial. Namun pada kenyataannya, beberapa hasil penelitian menunjukkan penyelenggaraan SMK termasuk 3 SMKN yang sebelumnya berstatus RSBI di kota Bandar Lampung masih menunjukkan kelemahan dalam berbagai aspek, salah satunya adalah dalam aspek tugas-tugas manajerial kepala sekolah. ${ }^{3}$ Fakta di atas, juga didukung oleh hasil uji kompetensi kepala sekolah yang dilakukan oleh Dirjen PMPTK Kemendiknas menemukan sekitar 70\% dari 250 ribu kepala sekolah di Indonesia tidak kompeten, dan secara mengejutkan terungkap bahwa penguasaan terhadap kompetensi manajerial baru mencapai $47,1 \%$.

Kompetensi manajerial itu sendiri merupakan kemampuan dan pemahaman kepala sekolah dalam pengelolaan sekolah. ${ }^{4}$ Kompetensi manajerial tersebut kemudian diimplementasikan dalam bentuk kinerja. Sebagaimana dinyatakan oleh Peterson yang menjelaskan bahwa performance is the application of competence to achieve success carry out a job. Lebih lanjut Karwati dan Priansa menguraikan kinerja kepala sekolah dalam melaksanakan tugas-tugas manajerial tersebut dapat dilihat dari berbagai aspek, yaitu: kemampuannya dalam menyusun perencanaan, pengembang- 
an organisasi sesuai kebutuhan, kepemimpinan kepala sekolah, mengelola perubahan, menciptakan iklim dan budaya sekolah, mengelola guru dan staf, peserta didik, administrasi dan kurikulum, mengelola sarana prasarana, serta memanfaatkan kemajuan teknologi bagi peningkatan pembelajaran dan manajemen sekolah. ${ }^{5}$

Berdasarkan fakta yang telah diuraikan di atas, maka kinerja kepala sekolah perlu senantiasa dtingkatkan dan dikembangkan. Untuk itu, diperlukan suatu evaluasi kinerja (performance appraisal), yaitu suatu proses yang dilakukan untuk memberikan penilaian terhadap hasil kerja atau prestasi kerja yang diperoleh organisasi, tim atau individu. ${ }^{6}$ Oleh karena itu tujuan penelitian tentang "Evaluasi Kinerja Kepala Sekolah Menengah Kejuruan Negeri (SMKN) di Kota Bandar Lampung" ini adalah untuk mengetahui kinerja kepala sekolah dalam: (1) memimpin sekolah terkait dengan pendayagunaan sumber daya sekolah, (2) mengelola perubahan dan pengembangan sekolah, (3) menciptakan budaya dan iklim sekolah, dan (4) memanfaatkan kemajuan teknologi informasi bagi pembelajaran dan manajemen sekolah.

\section{METODE}

Pendekatan atau model evaluasi yang digunakan dalam penelitian ini adalah model evaluasi berbasis tujuan dan digabung dengan model evaluasi yang pada umumnya dikembangkan pada beberapa lembaga pemerintah, sedangkan metode penelitian yang digunakan adalah adalah metode kualitatif. Proses pengumpulan data dilakukan melalui teknik wawancara, observasi dan telaah dokumen, informan dalam penelitian terdiri dari pengawas, ketua program studi, guru, staf administrasi, dan Komite sekolah. Analisis data dilakukan secara kualitatif. Di samping itu, untuk data yang diperoleh dari rubrik penilaian (wawancara terstruktur) dianalisis secara kuantitatif (statistik deskriptif) dengan rumus persentase.

\section{HASIL}

Deskripsi hasil analisis data dalam penelitian evaluasi ini dibagi kedalam empat komponen kinerja, yaitu kinerja: (1) memimpin sekolah terkait dengan pendayagunaan sumber daya sekolah secara optimal; (2) mengelola perubahan dan pengembangan sekolah menuju organisasi pembelajar yang efektif; (3) menciptakan budaya dan iklim sekolah yang kondusif dan inovatif bagi pembelejaran peserta didik; dan (4) memanfaatkan kemajuan teknologi informasi bagi pembelajaran dan manajemen sekolah. Secara lebih rinci hasil penelitian ini dapat disajikan sebagai berikut:

Kinerja pada komponen memimpin sekolah, diwujudkan melalui beberapa kegiatan yang sekaligus menjadi kriteria evaluasi dalam komponen ini, yaitu: (1) mengkomunikasikan visi, misi dan tujuan sekolah, (2) mengordinasi, mengarahkan dan memotivsi guru dan staf, (3) menjadi teladan dalam memanfaatkan sumber daya, (4) menunjukkan kedisiplinan, dan (5) membangun kerja sama tim. Keseluruhan hasil analisis data pada aspek memimpin sekolah dapat disajikan pada gambar 2 berikut ini: 


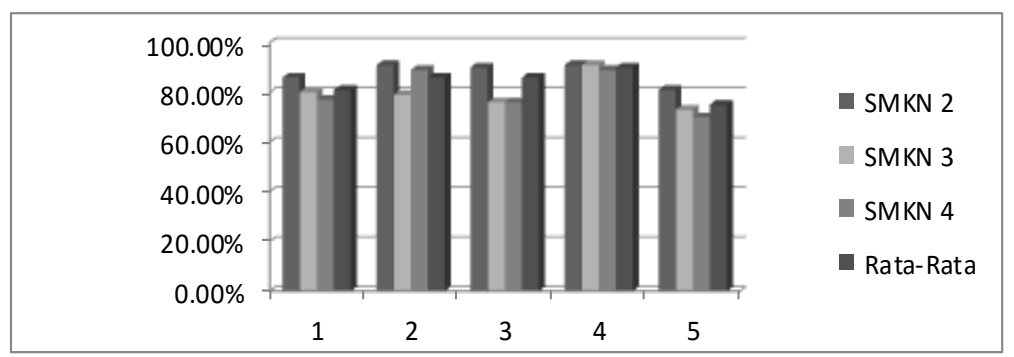

\section{Gambar 1. Grafik Persentase Skor Data Kinerja Kepala Sekolah pada Aspek Memimpin Sekolah}

Berdasarkan gambar 1, terlihat bahwa secara umum kinerja kepala sekolah dalam memimpin sekolah telah menunjukkan tingkat kinerja yang baik, yaitu ratarata aktualisasi kinerjanya mencapai $84 \%$. Komponen tersebut dapat dilihat dari ketercapaian lima kriteria yang menjadi tolok ukur tingkat kinerja memimpin sekolah, yaitu: kriteria 1 mencapai $81 \%$, kiteria 2 mencapai $86 \%$, kriteria 3 mencapai $86 \%$, kritteria 4 mencapai $90 \%$, dan kriteria 5 mencapai $75 \%$.

Dari lima kriteria evaluasi di atas, masih terdapat satu kriteria yang pencapaiannya masih berada pada kategori cukup (75\%), yaitu kriteria pada kegiatan membangun kerja sama. Dalam konteks penelitian ini kerja sama yang dimaksud adalah kerjasama sekolah dengan komite sekolah. Hasil penelitian menunjukkan bahwa, kepala sekolah dalam memimpin sekolah untuk pendayagunaan sumber daya sekolah, belum didukung oleh hubungan kerjasama yang optimal antara sekolah dengan komite. Kerjasama yang dijalin selama ini lebih kepada penggalangan dana dari masyarakat (komite), namun kurang menyentuh pada kepentingan sharing ide dan lahirnya gagasan-gagasan inovatif dari komite bagi kemajuan sekolah, hal ini disebabkan karena kurangnya intensitas komunikasi dan keterlibatan komite dalam kegiatan sekolah, serta kurangnya pemahaman komite itu sendiri akan kedudukan, peran, dan fungsinya sebagai komite sekolah.

Kinerja pada komponen mengelola perubahan diwujudkan melalui kegiatan dan menjadi kriteria evaluasi pada komponen ini, yaitu: (1) mengembangkan program baru (program inovatif) untuk meningkatkan pencapaian target sekolah yang lebih tinggi, (2) membangun tim kerja yang efektif, (3) menerapkan berbagai teknik pembaharuan dalam pengelolaan pembelajaran, dan (4) pengembangan potensi dan peningkatan prestasi sekolah. Keseluruhan hasil analisis pada aspek mengelola perubahan disajikan pada gambar 2. berikut ini: 


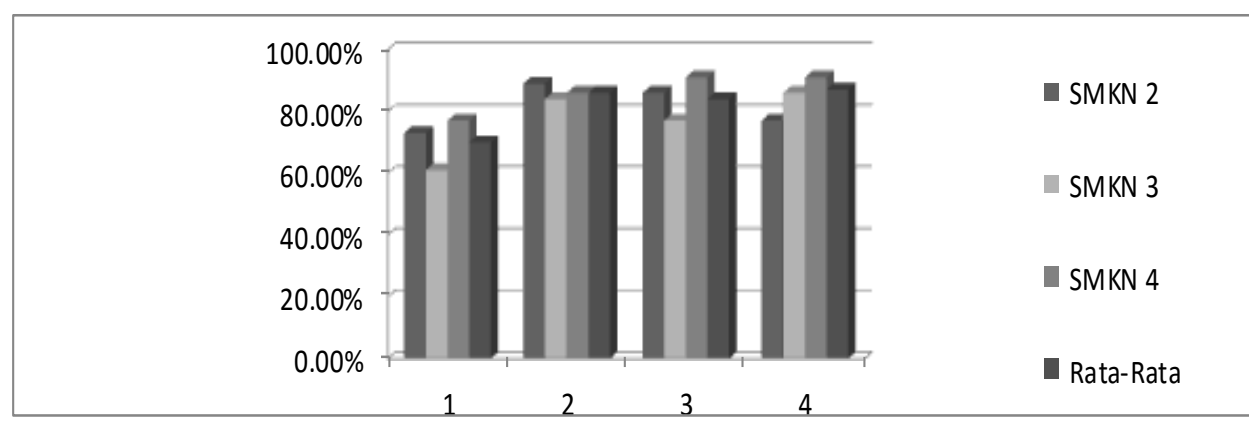

Gambar 2. Grafik Persentase Skor Data

Kinerja Kepala Sekolah pada Aspek Mengelola Perubahan

Berdasarkan gambar 2, terlihat bahwa secara umum kinerja kepala sekolah dalam mengelola perubahan telah menunjukkan tingkat kinerja yang baik, yaitu ratarata aktualisasi kinerjanya mencapai $82 \%$. Aspek tersebut dapat dilihat dari ketercapaian empat kriteria yang menjadi tolok ukur tingkat kinerja, yaitu: kriteria 1 mencapai 70\%, kriteria 2 mencapai 86\%, kriteria 3 mencapai $84 \%$, dan kriteria 4 mencapai $87 \%$.

Dari empat kriteria evaluasi di atas, masih terdapat satu kriteria yang pencapaiannya masih berada pada kategori cukup (70\%), yaitu kriteria pada kegiatan mengembangkan program baru untuk meningkatkan pencapaian target sekolah yang lebih tinggi. Dalam mengelola perubahan ini, kepala sekolah belum mampu mengembangkan program baru (program-program inovatif), kepala sekolah lebih cenderung melanjutkan program yang telah dilaksanakan pada periode sebelumnya. Selain itu, kepala sekolah belum maksimal dalam merespon dan mengapresiasi setiap kreativitas (inovasi) yang dihasilkan baik oleh guru, staf administrasi maupun siswa, serta belum membudayanya sistem reward untuk sebuah inovasi di lingkungan sekolah.

Kinerja pada komponen menciptakan budaya dan iklim sekolah diwujudkan melalui kegiatan dan menjadi kriteria evaluasi dalam komponen ini, yaitu: (1) memberi contoh dalam berbudaya mutu yang kompetitif, (2) mengelola lingkungan sekolah yang nyaman, bersih dan indah, (3) membentuk suasanan dan iklim kerja yang sehat, serta (4) menumbuhkan budaya kerja yang efisien, kreatif, dan inovatif. Keseluruhan hasil analisis data pada aspek mengelola perubahan tersebut dapat disajikan pada gambar 3 berikut ini: 


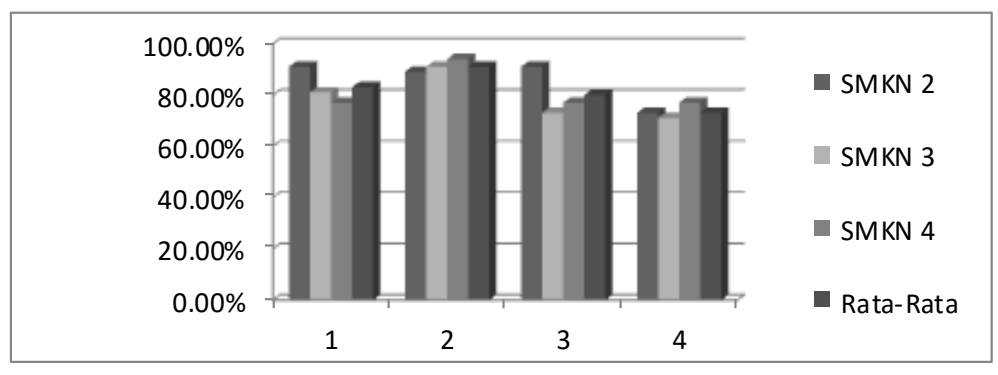

\section{Gambar 3. Grafik Persentase Skor Data Kinerja Kepala Sekolah} pada Aspek Menciptakan Budaya dan Iklim Sekolah

Berdasarkan gambar 3, terlihat bahwa kinerja kepala sekolah dalam mengelola perubahan telah menunjukkan tingkat kinerja yang baik, yaitu rata-rata aktualisasi kinerjanya mencapai $82 \%$. Aspek tersebut dapat dilihat dari ketercapaian empat kriteria yang menjadi tolok ukur tingkat kinerja, yaitu: kriteria 1 mencapai 83\%, kriteria 2 mencapai 91\%, kriteria 3 mencapai 80\% \%, dan kriteria 4 mencapai $73 \%$.

Dari empat kriteria evaluasi di atas, masih terdapat satu kriteria yang pencapaiannya masih berada pada kategori cukup (73\%), yaitu kriteria menumbuhkan budaya kerja yang efisien, kreatif, dan inovatif di lingkungan sekolah. Hasil penelitian menunjukkan, kepala sekolah belum mampu menumbuhkembangkan budaya kerja yang efektif, kreatif dan inovatif serta berorientasi pada pelayanan. Hal ini disebabkan karena masih belum maksimalnya pengembangan dan orientasi budaya kerja berbasis mutu di sekolah, sehingga intrenalisiaisi nilai-nilai tersebut dalam aktivitas sekolah juga menjadi rendah. Selain itu, semangat berkompetisi untuk meraih keunggulan dikalangan warga sekolah baik guru, staf sekolah maupun peserta didik juga belum dibangun secara optimal, sehingga kebanyakan guru atau staf sekolah bekerja apa adanya, sesuai tugas rutin mereka.

Kinerja pada komponen memanfaatkan TIK bagi peningkatan pembelajaran dan manajemen sekolah diwujudkan melalui kegiatan dan menjadi kriteria evaluasi dalam komponen ini, yaitu: (1) pengembangan sistem manajemen sekolah secara objektif dengan dukungan penerapan TIK, (2) pengelolaan pembelajaran dengan dukungan penerapan TIK, serta (3) pengembangan sistem pengelolaan perpustakaan secara efektif dengan dukungan penerapan TIK. Keseluruhan hasil analisis data pada aspek memanfaatkan teknologi informasi dapat disajikan pada gambar 4 berikut ini:

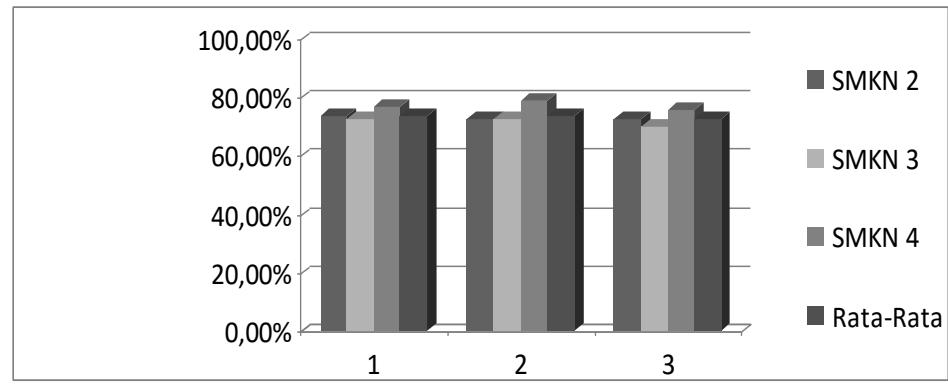

Gambar 4. Grafik Persentase Skor Data Kinerja Kepala Sekolahpada Aspek Memanfaatkan Teknologi Informasi 
Berdasarkan gambar 4, terlihat bahwa secara umum kinerja kepala sekolah dalam memanfaatkan TIK bagi peningkatan pembelajaran dan manajemen sekolah masih dalam kategori cukup, yaitu rata-rata aktualisasi kinerjanya baru mencapai $74 \%$. Aspek tersebut dapat dilihat dari ketercapaian tiga kriteria yang menjadi tolok ukur tingkat kinerja, yaitu: kriteria 1 mencapai 74\%, kriteria 2 mencapai 74\%, kriteria 3 mencapai $73 \%$.

Dari ketiga kriteria evaluasi di atas, seluruhnya menunjukkan pencapaiannya pada kategori cukup. Daam pemanfaatan TIK masih banyak ditemui guru dan staf sekolah yang enggan memanfaatkan teknologi tersebut. Berbagai alasan dikemukakan, baik menyangkut kompetensi SDM yang belum memadai, rendahnya kemauan/motivasi guru dalam memanfaatkan TIK, maupun terkait dengan keterbatasan sekolah dalam menyediakan sarana/teknologi yang diperlukan.

Berdasarkan hasil penelitian pada tiap-tiap aspek evaluasi di atas, dapat dibuat deskripsi umum tentang kinerja kepala SMKN kota Bandar Lampung pada gambar 6 berikut ini:

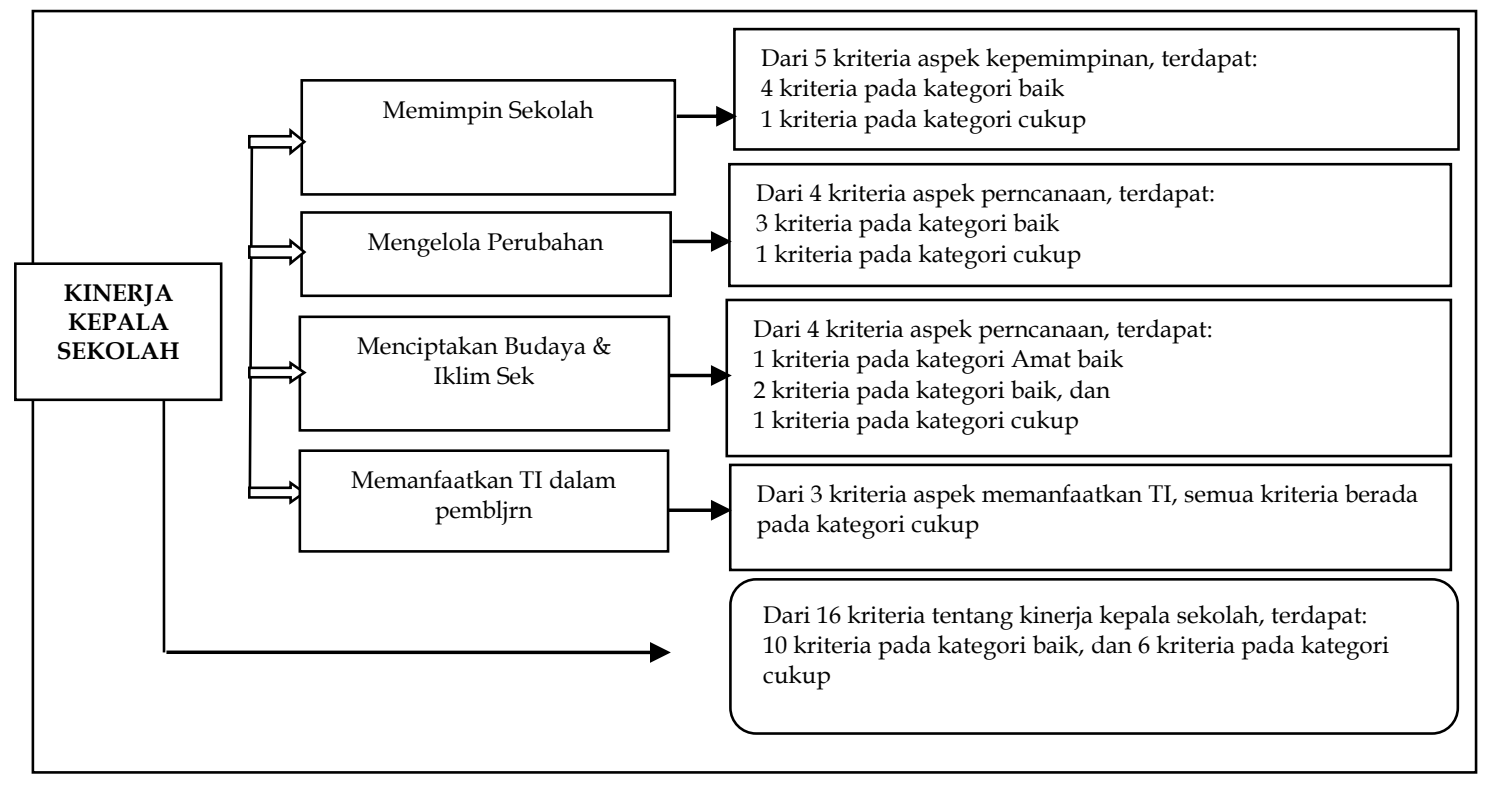

\section{Gambar 5. Skema Kinerja Kepala SMKN kota Bandar Lampung}

Berdasarkan gambar 5, dapat dijelaskan bahwa secara keseluruhan kinerja kepala SMKN kota Bandar Lampung yang diukur pada 4 aspek evaluasi dan dijabarkan ke dalam 16 kriteria, 10 kriteria telah terpenuhi dengan baik, dan 6 kriteria lainnya baru terpenuhi pada kategori cukup baik. Seanjutnya, hasil perhitungan data evaluasi yang dianalisis secara statistik deskriptif dengan menggunakan rumus persentase, kemudian dikonversikan dalam bentuk kategori kualitatif untuk menentukan aktualitas ketercapaian masing-masing kriteria kinerja kepala sekolah, secara rinci hasil perhitungan tersebut disajikan dalam tabel 1. berikut: 
Tabel 1. Hasil Evaluasi Kinerja Kepala SMKN Kota Bandar Lampung pada Seluruh Aspek Evaluasi

\begin{tabular}{|c|c|c|c|c|}
\hline NO & $\begin{array}{c}\text { ASPEK EVALUSI } \\
\text { KINERJA }\end{array}$ & $\begin{array}{c}\text { KEADAAN KRITERIA } \\
\text { PENCAPAIAN KINERJA }\end{array}$ & $\begin{array}{c}\text { AKTUALISASI } \\
\text { KETERCAPAIAN }\end{array}$ & $\begin{array}{l}\text { INTERPRE- } \\
\text { TASI } \\
\end{array}$ \\
\hline 1 & $\begin{array}{l}\text { Memimpin sekolah } \\
\text { dalam rangka } \\
\text { pendayagunaan } \\
\text { sumber daya } \\
\text { sekolah secara } \\
\text { optimal. }\end{array}$ & $\begin{array}{l}\text { Dari } 5 \text { kriteria pada aspek } \\
\text { memimpin sekolah terdapat } 4 \\
\text { kriteria pada pencapaian baik, } \\
\text { dan } 1 \text { kriteria pada pencapaian } \\
\text { cukup }\end{array}$ & $84 \%$ & Kinerja baik \\
\hline 2 & $\begin{array}{l}\text { Mengelola } \\
\text { perubahan dan } \\
\text { pengembangan } \\
\text { sekolah menuju } \\
\text { organisasi } \\
\text { pembelajar yang } \\
\text { efektif }\end{array}$ & $\begin{array}{l}\text { Dari } 4 \text { kriteria pada aspek } \\
\text { mengelola perubahan dan } \\
\text { pengembangan sekolah } \\
\text { terdapat } 3 \text { kriteria pada } \\
\text { pencapaian baik, dan } 1 \text { kriteria } \\
\text { pada pencapaian cukup }\end{array}$ & $82 \%$ & Kinerja baik \\
\hline 3 & $\begin{array}{l}\text { Menciptakan } \\
\text { budaya dan iklim } \\
\text { sekolah yang } \\
\text { kondusif dan } \\
\text { inovatif bagi } \\
\text { pembelajaran } \\
\text { peserta didik }\end{array}$ & $\begin{array}{l}\text { Dari } 4 \text { kriteria pada aspek } \\
\text { menciptakan budaya dan } \\
\text { iklim sekolah terdapat } 1 \\
\text { kriteria pada pencapaian amat } \\
\text { baik, } 2 \text { kriteria pada } \\
\text { pencapaian baik, dan } 1 \text { kriteria } \\
\text { pada pencapaian cukup }\end{array}$ & $82 \%$ & Kinerja baik \\
\hline 4 & $\begin{array}{l}\text { Memanfaatkan } \\
\text { teknologi } \\
\text { informasi dalam } \\
\text { dalam } \\
\text { pembelajaran dan } \\
\text { administrasi } \\
\text { sekolah }\end{array}$ & $\begin{array}{l}\text { Dari } 3 \text { kriteria aspek } \\
\text { memanfaatkan TI, semua } \\
\text { kriteria berada pada } \\
\text { pencapaian cukup baik }\end{array}$ & $74 \%$ & Kinerja cukup \\
\hline
\end{tabular}

\section{PEMBAHASAN}

Sebagaimana telah dipaparkan dalam hasil penelitian, kinerja kepala SMKN Kota Bandar Lampung pada tiga aspek evaluasi kinerja sudah menunjukkan tingkat pencapaian kinerja pada kategori baik, dan satu aspek evaluasi pada kategori cukup, yaitu aspek memanfaatkan teknologi informasi. Namun demikian, pada ketiga aspek yang berkategori baik, masih terdapat beberapa kriteria kinerja yang pencapaiannya belum memadai atau masih dalam kategori cukup. Lebih lanjut akan dijelaskan setiap kriteria yang masih dalam kategori cukup tersebut sebagai berikut:

Pada aspek memimpin sekolah dalam pendayagunaan sumber daya sekolah, kriteria yang belum dapat dipenuhi dengan baik (masih dalam kategori cukup), adalah terkait dengan kriteria membangun kerjasama tim dalam memajukan sekolah, terutama kerjasama antara sekolah dengan komite. Kerja sama tersebut merupakan suatu langkah penting yang harus dilakukan sekolah dalam rangka memperoleh dukungan dari masyarakat, karena menurut Indra Jati Sidi, jika komite sekolah dapat berperan dan berfungsi sebagimana mestinya, maka proses dan pelaksanaan pendidikan di sekolah-sekolah akan berjalan sesuai dengan prinsip-prinsip demokrasi. $^{7}$ 
Faktanya, sejauh ini hubungan sekolah dengan komite belum berjalan sebagaimana mestinya, hubungan tersebut lebih kepada memperoleh partisipasi masyarakat dalam penggalangan dana untuk bantuan biaya operasional sekolah, tetapi masih kurang menyentuh pada kepentingan sharing ide bagi kemajuan sekolah. Pada hal menurut Nanang Fattah, partisipasi masyarakat bukan hanya sebagai pendukung, tetapi sekaligus juga sebagai pemberi pertimbangan, pengontrol, dan sebagai mediator antara pemerintah dan masyarakat. ${ }^{8}$ Di samping itu, pengaruh partisipasi aktif masyarakat dalam pendidikan sangat luas, tidak hanya terbatas pada keuntungan yang diperoleh masyarakat di satu pihak, namun dapat meningkatkan performa sekolah secara keseluruhan, sebagaimana dikatakan Alison bahwa "parental partisipation can influnece not only a child's performance, but also the overal performance of the school." 9

Mencermati temuan di atas, ada berbagai faktor yang menjadi penyebab terjadinya kesenjangan hubungan kerjasama antara sekolah dengan komite pada SMKN kota Bandar Lampung, selain karena cenderung sekolah masih menempatkan komite sebagai mesin uang dan alat untuk melegitimasi berbagai kebijakan sekolah, juga disebabkan oleh komite itu sendiri secara internal, yaitu masih rendahnya kesadaran dan pemahaman masyarakattentang kedudukan, peran, dan fungsi komite.

Pada aspek mengelola perubahan menuju organisasi pembelajar yang efektif, kriteria yang belum dapat dipenuhi dengan baik (masih dalam kategori cukup), adalah terkait dengan kriteria mengembangkan program baru (program-program inovatif) untuk meningkatkan pencapaian target sekolah yang lebih tinggi. Untuk menciptakan gagasan-gagasan baru bagi pengembangan program inovatif sekolah, diperlukan kemampuan kepala sekolah dalam mengelola perubahan melalui peningkatan kemampuan dan kreativitas, serta pengembangan inovasi dari seluruh warga sekolah.

Dalam konteks ini, belum banyak hal-hal baru yang digagas oleh kepala sekolah dalam rangka pengembangan pogram-program inovatif di sekolah, baik dalam aspek akademik maupun adminsitratif. Yang umum terjadi adalah bahwa kepala sekolah lebih cendrung melanjutkan program-program lama yang telah dijalankan pada periode sebelumnya. Ide-ide kreatif guru dan staf belum didukung atau direspons dengan kebijakan yang lebih kongkrit. Jika merujuk pada apa yang dikemukakan Handoko bahwa manajer harus senantiasa mengantisipasi perubahanperubahan dalam lingkungan yang akan mensyaratkan penyesuaian-penyesuaian desain organisai di waktu mendatang, dan perubahan itu dapat berwujud perkembangan teknologi, ekonomi dan politik, kualitas dan sikap karyawan, dan sebagainya. ${ }^{10}$

Mencermati temuan di atas, ada beberapa faktor yang menjadi penyebab belum optimalnya kemampuan kepala sekolah dalam mengembangkan program-program baru (inovatif) guna meningkatkan target pencapaian sekolah yang lebih tinggi pada SMKN kota Bandar Lampung, yaitu inovasi belum menjadi sebuah kebutuhan dilingkungan sekolah sehingga inovasi hanya berpusat pada segelintir orang saja. 
Selain itu, lemahnya berbagai faktor penunjang khususnya terkait dengan ketersediaan sumber daya dan komitmen pimpinan sehingga mengakibatkan tidak berkembangnya inovasi di sekolah, pada hal menurut Thomas dan Bennis salah satu cara penanganan perubahan itu adalah melalui program perubahan yang direncanakan (planned change), yaitu sebagai perancangan dan implementasi inovasi struktural, kebijakan atau tujuan baru, atau perubahan dalam filsafat, iklim dan gaya pengoperasian secara sengaja. Hambatan lainnya adalah belum membudayanya sistem reward untuk sebuah inovasi, terutama yang bernilai ekonomis serta memilki daya tarik sedemikian rupa sehingga merangsang para guru/tenaga kependidikan untuk melakukan inovasi dengan penuh dedikasi. ${ }^{11}$ Padahal menurut Yukl sejumlah pedoman untuk menciptakan kondisi yang menguntungkan untuk belajar dan inovasi, antara lain: mendorong pemikiran sistem, membantu orang untuk memahami dan meningkatkan model mental mereka, mendorong eksperimentasi, mendapat pengetahuan dari luar, mendorong inovasi dan aktivitas usaha, memberi penghargaan belajar dan inovasi. ${ }^{12}$

Pada aspek menciptakan budaya dan iklim sekolah yang kondusif dan inovatif, kriteria yang belum dapat dipenuhi dengan baik (masih dalam kategori cukup) adalah terkait dengan kriteria menumbuhkan budaya kerja yang efisien, kreatif, inovatif dan berorientasi pada pelayanan prima. Salah satu karakteristik sekolah efektif adalah sekolah yang memiliki budaya kerja yang efisien, kreatif dan inovatif dalam mencapai tujuan sekolah. Namun faktanya, dalam proses pencapaian tujuan tesebut sekolah seringkali dihadapkan pada berbagai kendala dalam menumbuhkan budaya kerja yang efisien, kreatif, inovatif dan berorientasi pada pelayanan prima.

Mencermati temuan di atas, ada beberapa faktor yang menjadi penyebab belum optimalnya upaya menumbuhkan budaya kerja yang efisien, kreatif, inovatif pada SMKN kota Bandar lampung, di antaranya; belum optimalnya kemampuan kepala sekolah mengembangkan budaya kerja yang berorientasi pada pelayanan prima, baik bagi pelanggan internal maupun eksternal sekolah. Jika merujuk pada pendapat Anwar, dia menjelaskan bahwa pengembangan dan penerapan budaya organisasi sangat ditentukan oleh pimpinan organisasi, pimpinan organisasi harus memiliki komitmen kuat dalam penerapan budaya, setelah itu baru kemudian diinternalisasikan pada personil lainnya. ${ }^{13}$

Selanjutnya, kendala lain dalam menciptakan budaya dan iklim sekolah adalah masih rendahnya semangat kompetisi dikalangan guru dan staf administrasi sekolah dalam meraih keunggulan dan prestasi, masih terbentuk kelompok-kelompok informal di sekolah yang kurang menguntungkan bagi kemajuan sekolah. Kondisi di atas, menunjukkan bahwa upaya menumbuhkembangkan budaya sekolah belum sampai pada mendorong tumbuhnya budaya kualitas dikalangan warga sekolah. Padahal, Greenberg dan Baron mengatakan bahwa fungsi dasar budaya organisasi adalah "provides a sense of identity for members, enchances commitment to the organization's mission, clarifies and reinforces standards of behaviors.", yaitu memberi makna identitas, meingkatkan komitmen, memperjels dan memperkuat standar prilaku. 
Pada aspek memanfaatkan teknologi informasi dalam pembelajaran dan manajemen sekolah, ketiga kriteria belum dapat dipenuhi dengan baik (masih dalam kategori cukup), yaitu kriteria pengembangan sistem pembelajaran, sistem pengelolaan administrasi, serta pengembangan sistem pengelolaan perpustakaan dengan dukungan penerapan TIK. Pemahaman dan penguasaan dasar TIK menjadi bagian penting dari pendidikan, kehadirannya tidak bisa ditawar-tawar lagi. Namun faktanya masih banyak sekolah yang belum optimal memanfaatkan TIK baik dalam pembelajaran maupun pengelolaan adminstrasi sekolah. Jika merujuk pada pendapat Sells \& Richey Edi, menjelaskan bahwa potensi teknologi instruksional itu adalah meningkatkan produktivitas pendidikan, memberikan kemungkinan pendidikan yang sifatnya lebih individual, memberikan dasar pembelajaran yang ilmiah, meningkatkan kemampuan pembelajaran, memungkinkan belajar lebih akrab, dan memungkinkan pemerataan pendidikan yang bermutu. ${ }^{14}$

Selain itu, kahadiran TIK di sekolah harus dibarengi dengan menyiapkan sumber daya manusia yang kompeten, siap dan memilki kemauan (motivasi) yang tinggi dalam memanfaatkan teknologi tersebut dalam pekerjaan mereka. Sebagaimana yang diungkapkan Ruud, bahwa investasi TIK di sekolah-sekolah yang kemudian diikuti dengan pengembangan kompetensi guru dan siswa dalam bidang TIK dapat memperbaiki efektifitas pengelolaan sekolah serta meningkatkan kinerja (performance) akademik tenaga kependidikan dan peserta didik. ${ }^{15}$ Kemampuan dan komitmen kepala sekolah dalam membangun jaringan telekomunikasi yang memadai dan dijadikan sebagai pusat informasi bagi sekolah, alumni dan masyarakat pada umumnya, merupakan kebutuhan yang sudah selayaknya dipenuhi oleh sekolah pada saat ini.

\section{SIMPULAN}

Berdasarkan pembahasan hasil evaluasi, yaitu dengan membandingkan kriteria dengan pencapaian masing-masing aspek yang dievaluasi, maka dapat disimpulkan hal-hal sebagai berikut:

Hasil evaluasi kinerja kepala sekolah pada aspek memimpin sekolah dalam rangka pendayagunaan sumber daya sekolah, secara umum telah menunjukkan tingkat pencapaian kinerja yang baik, namun masih terdapat satu krietria yang belum terpenuhi atau masih dalam kategori cukup, yaitu dalam hal membangun kerjasama dengan komite sekolah dalam memajukan sekolah.

Hasil evaluasi kinerja kepala sekolah pada aspek mengelola perubahan menuju pembelajaran yang efektif, secara umum telah menunjukkan tingkat pencapaian kinerja yang baik, namun masih terdapat satu krietria evaluasi yang belum terpenuhi atau masih dalam kategori cukup, yaitu dalam hal pengembangan program baru (program inovatif) untuk meningkatkan pencapaian target sekolah yang lebih tinggi.

Hasil evaluasi kinerja kepala sekolah pada aspek menciptakan budaya dan iklim sekolah yang kondusif dan inovatif bagi pembelajaran peserta didik, secara umum telah menunjukkan tingkat pencapaian kinerja yang baik, namun masih 
terdapat satu krietria yang belum terpenuhi atau masih dalam kategori cukup, yaitu dalam hal menumbuhkan budaya kerja yang efisien, kreatif, inovatif dan berorientai pada pelayanan prima.

Hasil evaluasi kinerja kepala sekolah pada aspek memanfaatkan teknologi informasi bagi pembelajaran dan manajemen sekolah, secara keseluruhan menunjukkan tingkat pencapaian kinerja masih dalam kategori cukup.

\section{CATATAN AKHIR:}

1. Suyanto, Perumusan Manajemen Berbasis Sekolah; htt://media.diknas.go.id/document. (diakses, 14 April 2013)

2. Euis Karwati dan Donni Juni Priansa, Kinerja dan Profesionalisme Kepala Sekolah. Bandung, Alfabeta, 2013, h. 82.

3. Undang Rosidin, dkk, Evaluasi Kinerja Penyelenggaraan RSBI di Kota Bandar Lampung. Hasil Laporan Penelitian, Bandar Lampung, 2011.

4. Suhardiman, 2012; 42)

5. Euis Karwati dan Donni Juni Priansa, op.cit., h. 122.

6. Wibowo, 2007:351)

7. Indra Jati Sidi, Menuju Masyarakat Belajar. Jakarta, Paramadina, 2003, h. 135.

8. Nanang Fattah (2003:9)

9. Alison (2000:8)

10. Handoko $(2001 ; 317)$

11. John M Thomas dan Warren G. Bennis. The Management of Change and Conflict. Penguin Books, Baltimore, 1972, h. 209.

12. Gary Yukl, Kepemimpinan dalam Organisasi.Edisi Bahasa Indonesia. Jakarta, Indeks Kelompok Gramedia, 2005, h. 354.

13. Anwar $(2005 ; 118)$

14. Sells \& Richey Edi $(1994 ; 17)$

15. Ruud $(2005 ; 89)$

\section{DAFTAR PUSTAKA}

Danim, Sudarwan. Visi Baru Manajemen Sekolah: Dari Unit Birokrasi ke Lembaga Akademik. Jakarta: Bumi Aksara, 2007.

Sidi, Indra Jati, Menuju Masyarakat Belajar. Jakarta, Paramadina, 2003.

Mangkunegara, Anwar Prabu . Perilaku dan Budaya Organisasi, Bandung: Refika Aditama, 2005

Karwati, Euis dan Donni Juni Priansa, Kinerja dan Profesionalisme Kepala Sekolah. Bandung, Alfabeta, 2013

Rosidin, Undang dkk, Evaluasi Kinerja Penyelenggaraan RSBI di Kota Bandar Lampung. Hasil Laporan Penelitian, Bandar Lampung, 2011.

Suyanto, Perumusan Manajemen Bebrbasis Sekolah; htt://media.diknas.go.id/document. (diakses, 14 April 2013)

Thomas, John M dan Warren G. Bennis. The Management of Change and Conflict. Penguin Books, Baltimore, 1972.

Wirawan, Evaluasi: Teori, Model, Standar, Aplikasi dan Profesi. Jakarta, Rajawali Pers, 2011.

Yukl, Gary. Kepemimpinan dalam Organisasi.Edisi Bahasa Indonesia. Jakarta, Indeks Kelompok Gramedia, 2005. 